\section{SAFETY IN MINES RESEARCH BOARD}

\section{ANNUAL REPORT}

A LWAYS in the past a document of unusual interest, the twentieth annual report of the Safety in Mines Research Board fully maintains the standard of previous issues. Considerably slimmer than its predecessors, the report nevertheless clearly demonstrates the far-reaching importance of the Board's many avenues of research-all directed to the common end of saving life and limb in coal mines.

\section{Coal Dust Explosions}

Major disasters in British coal mining have almost invariably been associated with explosions of coal dust, and for many years it has been known that incombustible dusts, if present in sufficient proportion, were capable of suppressing such explosions. That no finality has been reached in the problem of eliminating coal dust explosions is shown by the report. Mechanized mining has inevitably resulted in an increase in the quantity of fine dust produced during mining operations, and under a grant from the Board, the British Colliery Owners' Research Association is carrying out investigations in the reduction and collection of dust in fully mechanized workings. Water sprays, working under a pressure of $120 \mathrm{lb}$. per sq. in., are being used as a means of reducing the amount of dust carried away by the air current during the loading of tubs. A similar method is being tested for the suppression of the dust made during coal-cutting operations with a machine adapted for over-cutting.

Investigations continue on the use of stone dust as a means of suppressing coal dust explosions. The results of one series of experiments serve to emphasize the importance of the stone dust and the coal dust being in intimate mixture. Incombustible dusts in contact with a humid atmosphere are subject to 'weathering', that is, the dust becomes less . dispersable. Experiment shows that the lower the proportion of particles of less than 10 microns in diameter, the higher the dispersability; attempts have been made, with some success, to prepare dusts with an unusually small proportion of ultra-fine particles.

\section{Electrical Research}

The casing of flame-proof apparatus must be strong enough to withstand the pressure of an internal firedamp explosion. A useful item of information for manufacturers of such apparatus is that a static pressure is a true measure of the ability of a casing to resist an internal explosion. Hydraulic or pneumatic pressure can, therefore, be used to ascertain the factor of safety of the casings.

\section{Mining Explosives}

Further work on sheathed explosives confirms the value of the sheath of inert material as a means of preventing ignitions of firedamp when shotfiring. It is the general practice in Great Britain to fire shots singly, but many mining engineers hold the view that the wider application of simultaneous shotfiring would not only result in a great saving of time, but also increased safety. The objection to this method of shotfiring is the danger of undetected missfires, but the results of the Board's investigations on this subject are reassuring. In the pits of one colliery company, some 3,500 shots per month are being fired in series of five and six together. Practical results are reported as excellent, and in the course of a year, the sole miss-fire was due to a defective exploder.

\section{Falls of Ground}

In this all-important branch of the Board's activities, much work continues to be carried out both in the laboratory and underground. A major problem created by the War is that of maintaining a sufficient supply of supporting materials for the coal mines of Great Britain. Prior to the War, the bulk of the pitwood was imported-chiefly from the Baltic States and Russia; with shipping engaged on even more urgent tasks, every effort has to be made in providing substitute materials for support. Investigations have been carried out on the relative strengths of home-grown and imported timber, and the importance of seasoning is demonstrated by an experiment in a wárm return airway. As a result of a short period of seasoning under these conditions, the strength of the timber was increased by 20 per cent.

With the object of conserving timber and steel, consideration has been given to the use of concrete underground. It would seem that the use of concrete supports at the working face has met with but a limited measure of success; concrete is apparently not well suited to the "repeated setting, loading and unloading", which is the lot of all face supports. Where concrete supports are used at the working face, particular attention must be given to the packing of the goaf, so as to reduce the convergence between roof and floor to the absolute minimum. To prevent premature failure some yielding device is necessary, or the props must be allowed to penetrate the floor. On roadways the use of concrete has proved to be more successful; concrete slabs have been used as struts between steel arches, and these remained unbroken although the arches were severely distorted.

Normally a task of major importance, the work on falls of ground and roof supports assumes a special significance under present conditions, and the report clearly indicates that the Board is playing a full part in investigating the use of new supporting materials and methods of support-research which is vitally necessary if supplies of steel and timber in Great Britain are to be conserved.

H. HaRTLEy.

\section{FORESTRY IN TRINIDAD AND TOBAGO}

$\mathrm{T}$ HE Annual Report of the Conservator of Forests of Trinidad and Tobago for the year 1941 (Council Paper No. 25 of 1942. Govt. Printer, Trinidad, 1942) gives a brief summary of the present position of the general forest policy for the Colony. Reservation of forests except in the western portion of the Northern Range alluded to in former reviews of these reports is considered eminently satisfactory. Since forest reserves occupy 22 per cent of the total area of the Colony, Trinidad and Tobago may be regarded as setting an example of a high average to many other Colonies which are still far behind this standard.

In forest management as reflected by working plans the Colony is in an exceptional position. It is some years now since the head of the forestry administration set himself the task of drawing up preliminary 